\title{
Civilisations
}

Revue internationale d'anthropologie et de sciences

humaines

40-1 | 1991

L'Asie et le Pacifique

\section{The Asian Newly Industrialized Economies: A Universal Model of Action}

\section{Michèle Schmiegelow}

\section{OpenEdition \\ Journals}

Electronic version

URL: http://journals.openedition.org/civilisations/1682

DOI: $10.4000 /$ civilisations. 1682

ISSN: 2032-0442

\section{Publisher}

Institut de sociologie de l'Université Libre de Bruxelles

\section{Printed version}

Date of publication: 1 January 1992

Number of pages: 133-171

ISBN: 2-87263-063-5

ISSN: 0009-8140

\section{Electronic reference}

Michèle Schmiegelow, «The Asian Newly Industrialized Economies: A Universal Model of Action », Civilisations [Online], 40-1 | 1991, Online since 07 July 2009, connection on 30 April 2019. URL : http:// journals.openedition.org/civilisations/1682; DOI : 10.4000/civilisations.1682

This text was automatically generated on 30 April 2019.

(c) Tous droits réservés 


\title{
The Asian Newly Industrialized Economies: A Universal Model of Action
}

\author{
Michèle Schmiegelow
}

\section{Introduction}

1 The Asian newly industrialized economies (NIE's), namely Hong Kong, South Korea, Singapore and Taiwan are attracting world-wide attention for five layers of reasons:

1. There is quasi-unanimity in recognizing them as success stories in industrial development and economic growth.

2. They are being discussed and they consider themselves as conceivable members of the OECD or an OECD-like organisation in the Pacific region.

3. They constitute an implicit, if not yet fully articulated challenge to less performing countries and regions, such as the Soviet Union and Latin America.

4. They invite intellectual anticipation of the conceivable outcome of Deng's and Gorbatchev's modernisation efforts in the two great Communist economies ${ }^{1}$.

5. They are recognized by some, but by no means all members of the academic community, as part of a new Pacific power center with Japan as its center ${ }^{2}$, and in potential competition with the North American, Soviet and Western European power centers in an increasingly multipolar world.

Inevitably, the question arises what precisely these "four tigers" have in common to explain such an outstanding performance. Given the wide array of salient structural differences between the Four, the task of finding an answer to that question is far from 
easy. It requires readiness to cut across familiar cleavages of economic theory and political doctrines.

3 Much of the empirical material of the economic histories of the Four in the past two or three decades is well known and I do not intend to reproduce it here in any detail. Just to put their performance in perspective, let look at the following figures:

- The Asian NIEs averaged yearly growth rates of $10 \%$ from 1965 to 1973, just above Japan's rate and more than double that of all other OECD countries.

- The average for the following fourteen years from 1973 to 1987 during which growth rates everywhere declined drastically, still reached 7,7 \%, two times that of Japan and three times that of the OECD as a whole.

- In 1987 the Four achieved a combined current account surplus of US \$30 billion contrasting starkly with the US \$ 5 billion deficit of the EC without Germany's US \$ 45 billion surplus.

- Their share of world trade in manufactured goods increased from $4 \%$ in 1975 to $11 \%$ in 1987, just short of the share of each of the three leaders in world exports, the US, West Germany and Japan.

- With a share of $8 \%$ in US imports, Taiwan alone has overtaken West Germany (5\%) in the rank list of America's most important trading partners coming up behind Canada and Japan!

So far the perspective. Table 1 gives an overview of the importance of trade for the NIES. But the challenging problem is not to describe that performance, but to explain it.

What I would like to propose is a model of action. I submit that only on the level of analysis of economic policy action, both private and public policy, both corporate and government action, can we find:

- what is common to the Four,

- what distinguishes them from less performing economies,

- what, hence, prima facie explains their own outstanding performance, and, finally,

- what may serve as a normative prescription to other countries or as an analytical tool for predicting outcomes of modernisation efforts elsewhere.

This is not to deny the importance of structures in the four newly industrialised economies:

7 There are societal structures and economic structures, there are macrostructures and microstructures, there are structures based on culture and structures that are merely the consolidated result of political regimes and/or past economic policies. More particularly, the Four share a fundamentally conservative political culture and, most interestingly, this is a point they have in common with Japan, in many aspects considered it their model. The political culture in question is no doubt distinguished by three features:

1. a comparative strength of the traditional family;

2. a basically unquestioned vitality of the social function of religion, be it Buddhism, Confucianism or Christianity;

3. dynamic fusions of corporatism, bureaucracy and capitalism casting doubt on Max Weber's sociology of religion and suggesting the religious and ideological pluralism of the capitalist world ${ }^{3}$.

One could point out that there is much dedication to traditional family, an unquestioned acceptance of the social function of religion, a rather more unbridled capitalism, as well as a sometimes pervasive influence of corporatist structures in Latin America as well. Classical Chinese, French, Prussian and Japanese bureaucracies share comparable legal structures and traditional ideals. Central European and Japanese corporatism have much 
in common ${ }^{4}$. Taiwan's neoclassical policy of competition is closer to West Germany's ordo-liberal policy than to the fair trade regime of any other country ${ }^{5}$. Hongkong's laissez-faire regime is perhaps the only application of 18th century Scottish liberalism surviving in the world. The list of confusing structural comparisons could be continued.

In order to overcome this confusion I shall proceed in two steps: First I shall define the model of action that makes the experience of the four Asian newly industrialised economies universally relevant (Section 2). Secondly, I shall refer to some of the most commonly accepted empirical material of the economic history of the four tigers and discuss how it fits the model of action (Section 3).

\section{The Model of Action}

10 I submit five propositions, which, taken together, should serve to cut the gordian knot of structural diversity and common performance among the Asian NIE'S. They shift the discussion to the level of analysis of the philosophy of science, but again, only on that level can we discover the global significance of the performance of the newly industrialised economies. These propositions were developed to explain the case of Japan ${ }^{6}$ . But they are of equal relevance to the "four tigers":

\section{Proposition One}

11 In order to explain economic performance, a crucial distinction must be made, which all explanations of the success of the "four tigers" have failed to make so far: the distinction between action and structure. Experts on China, Korea and South-East Asia have for centuries been focusing on the perceived unique societal structures of the countries in question. Even today they tend to treat economic policy action evolving in the environment of these Asian societies more or less as part of those structures. Since such culturally determined structures cannot be transplanted elsewhere, the economic policies that come along with them, as it were, cannot be emulated by policy-makers of other societies, is then the more or less implicit assumption.

12 Economists of the current mainstream persuasion, on the contrary, focus on the application of general equilibrium theory to the cases under study, are uninterested in both structures and economic policy action and quite consequently do not recognize the problem of interaction between structure and action. We argue that there are systems of action that can function in more than one societal environment, and that the economic policies of governments and corporations of the "four tigers", in spite of all differences, constitute precisely such a system of action. The differences are differences in degree and concrete configuration, but not in kind. There is, of course, interaction between structure and action. This is not limited to one-way causation but operates both ways. Economic policies can bring about structural change. When pursued over the long term, their effects can be consolidated to become, in turn, new structures. This is true both for developing and so-called "mature" economies.

\section{Proposition Two}

Although the newly industrialised Asian economies, their societies and cultures are unquestionably as unique as those of any other country in this pluralistic world, they 
contain many more components comparable to one or the other Asian or "Western" economy, society or culture than is generally assumed even by representatives of the general equilibrium approach to economic theory. In fact, there is hardly a component in the "four tigers" performance, both in terms of action and in terms of structure, that cannot be explained by some "Western" theory or concept. Only the concrete mix of these components is unique to each of the four economies. They are what we call "incomparable compositions of comparable components".

\section{Proposition Three}

14 Of the three types of explanation recognized by the philosophy of science, the causal one as in the physical sciences, the intentional one as in the rational choice theories of mainstream economics, and the functional one as in evolution theory in various disciplines, only the last-mentioned is adequate to deal with that challenge. The ex ante explanatory power of functionalist theory in the social sciences is debatable ${ }^{7}$. But there is no way to avoid it, whenever the question is asked ex post, why one mature economy performed better or worse than other mature economies. Many may not realize it, when they ask that question, but it is, of course, a functionalist one ${ }^{8}$. One advantage of functional explanation is that it is more inclusive than both causal and intentional methodologies, and, more particularly, does rely on these two wherever possible. An oldfashioned and much-decried set of concepts, namely Talcott Parsons' functionalist framework of adaptation, goal attainment, pattern maintenance and integration ${ }^{9}$ is surprisingly helpful in distinguishing true from spurious disagreements between the general equilibrium approach, the structural explanations, and the "statist" or mercantilist interpretations of Asian economies.

There is at least one of today's contending schools of thought about Asian economic performance for each of Parsons' functional requirements. In fact, general equilibrium theories and the "Austrian" school deal with "adaptation", the theory of economic policy and the neomercantilist paradigm with "goal attainment", structural approaches with "pattern maintenance", and decision-making analyses with "integration". The problem with these contending approaches is that some of them assume to have a complete explanation of performance or normative prescription for policy, while in fact they are engaged in an unintended division of labour. The enormous epistemological merit of the Japanese case is to show how such a division of labour actually works. The performance of the "four tigers" in emulating the Japanese model suggests the necessity of such division of labour in these cases as well.

\section{Proposition Four}

16 18th century "laissez-faire" liberalism is not the only political regime in which critical rationalism can flourish, as Karl Popper ${ }^{10}$, and with him the "Austrian School"11, strongly feel. Popper and Hayek might feel vindicated by the survival of Hong Kong's laissez-faire economy, society, and political system. But among the Asian economies it is the only one to have such a system. On the other hand, Japanese economic policy-makers have not only demonstrated over the past two decades that this most Western of all epistemological approaches can be practiced with great benefit, even in an as highly structured political and economic system as Japan's. It is in this very area where they 
have outperformed their Western counterparts most strikingly. South Korea, Taiwan and Singapore each occupy a different position in the spectrum of societal and economic organisation between the Japanese and Hong Kong ideal types. But their economic policies are inspired by the same readiness to invest, innovate and adjust, the same Schumpeterian dynamism, the same preparedness to discard fallible theories, in short, the same critical rationalism.

\section{Proposition Five}

17 From the four preceding propositions we conclude what could serve as the best line of Asian defence against American trade recriminations: Asian policy-makers have applied more thoroughly than their American colleagues an American philosophy, the philosophy of pragmatism. Pragmatism is the most important common cultural value and, moreover national, virtue of the U.S. and East Asia, and it is not by chance that the American and Asian economies can also boast the most dynamic performance, in global comparison, of the past two decades. Europe, which throughout its history seems to have been too preoccupied with dogmas to ever develop a lively pragmatic tradition, would be well advised to realize this combined American and East Asian potential. Such awareness could help to overcome the doctrinal battles between British Thatcherism, French dirigisme, German ordo-liberalism, Keynesian demand management industrial policy on the supply side, monetarist limitation to money-supply control, free-trade idealism and protectionist realism. Latin America, if it wishes to emulate the "four Asian tigers" must strive to rid itself of the excessive practice of doctrines received, during its postColumbian history, from Europe, from Spanish absolutism, over the liberal revolution, untrammelled capitalism, and quasi-feudal oligarchy, to the Marxist revolution. Hopefully, the trend towards democracy that has seized Latin America will prepare that region intellectually for pragmatic approaches to economic development, based on gradual elimination of social disequilibria, socialization of know-how, and integration of communities of different ethnic origin. Pragmatism appears to be the therapy Deng and Gorbachev are trying to administer to the two great ailing economies of the communist world, though with different results, and all of a sudden, Marxist revolutionaries and conservative doctrinarians alike are deprived of their enemies.

18 The rejection of a system of "great truths" governing all human activity is the "positive" substance of Charles Pierce's, William James' and John Dewey's philosophical pragmatism ${ }^{12}$. Strictly speaking, it is not a philosophy, but a technique for the solution of philosophical, scientific, economic and political problems. Theories are put in the service of practice case by case in pursuit of tentative goals. The recognition of uncertainty is as important to pragmatism as it is to critical rationalism. The eclectic use of theories (even deterministic ones, but without their deterministic ambition) is common both to pragmatism and to Parsonian functionalism.

19 Asia's pragmatic policy-makers have managed to combine conventional economic policy seeking incremental results in an assumed general equilibrium framework, and comprehensive "visions" aiming at more than incremental structural change. Moreover, in addition to aggregate methodology in fiscal and monetary policies of the Keynesian type, we find a surprising degree of methodological individualism ${ }^{13}$ not only in the action of private "Schumpeterian" entrepreneurs, but also in that of "visionary" industrial policy-makers of the Japanese type. Both categories of actors have had no difficulty in 
making the often neglected distinction between political and methodological individualism, and were thus never inhibited by Popper's, Schumpeter's, and Hayek's aversion against economic policy-making of any kind on the macro-level. They seem to be like Popper's "piecemeal engineers"14, trying their best to influence the otherwise autonomous course of Parsons' great "moving equilibrium". This equilibrium is a societal one. It includes Pareto's (static) economic equilibrium, but subjects it to the "movement" resulting from the interaction between economy, society, and culture.

Economic policy-makers of this type stand out for their always-maintained sense of direction. In that sense their policy-making can be called strategic. But their strategy is not dictated by doctrine. As true pragmatists, they derive their sense of direction from the nature of the changing problems to be solved. My husband and I have labelled Japanese policy-making of this type "strategic pragmatism ${ }^{15}$. The model of action of newly industrialised economies is the same.

\section{Explaining the Asian Performance}

21 There are two ways to make plain how easily the available empirical material of the Asian newly industrialised economies falls into the categories of the five propositions just stated.

- The first is to compile the components that are obviously comparable. This compilation shows that there are not one, but several theories that can claim Asian compliance. If their explanatory or normative ambition is to be recognized fully, they cannot prevail at the same time. The result is a powerful suggestion of the functional quality of pragmatic policymaking, both private and public. I will attempt such a compilation, although a very summary one, presently.

- But I will then proceed to a second, more structured way of organising the empirical material by trying to subsume it under the four Parsonian functions of adaptation, goal attainment, integration, and pattern maintenance. This approach is helpful in showing that a division of labour is possible between the conflicting theories, that functional holism and critical rationalism are indeed compatible.

\section{Pragmatic cuts across doctrines}

At least five components are common to the four economies that are the first to overcome the Asian Drama, which Gunnar Myrdal had considered almost unsolvable twenty years ago ${ }^{16}$. A strong suggestion that the five components have something to do with that performance can be derived from their presence in the case of Japan's modernisation process since the Meiji restorations. The suggestion is all the stronger, as it is often said that the Asian NIEs are following the Japanese model, and might in the predictable future outperform Japan in sectors in which Japan plays a leading role:

The first component is active government involvement in economic goal setting and a non-ideological acceptance of that role by private enterprises. There is no Asian inscrutability involved in this component. Indeed, one can refer to Alexander Gerschenkron's "theory of backwardness", which he developed from the economic history of continental Europe ${ }^{17}$. The more backward an economy, the theory states, the more active the role of government in the initial kick and subsequent spurt of economic development. The theory has the merit of recalling that there were times when European 
economies such as the German one were themselves developing economies, and that as recently as the nineteenth century. Harvard's Charles Kindleberger who, like hardly anyone else, combines authority in neoclassical theory with profound knowledge of European economic history, has the merit of having saved the legitimacy of active pragmatic government involvement even for mature economies in his "theory of the Second Best", which relies on markets as long as markets function efficiently, but which advocates government involvement whenever they do not ${ }^{18}$.

On the scale of comparative intensity of government involvement, South Korea ranks without any doubt highest among the Four. In the Gerschenkron approach, it is the one of the Four that comes closest to the Japanese model. Hong Kong ranks lowest, but the Crown Colony's government was active nonetheless, most recently with a support program for Hong Kong's electronics industry, which was showing signs of loosing out against Taiwanese and Korean competition. To be sure, this unexpected spur of Hong Kong government's activism was certainly more inspired by the more modest theory of Second Best than by the more radical theory of backwardness. Singapore and Taiwan occupy the middle with a sustained Gerschenkron type approach qualified by strong and progressive attachment to general equilibrium theory.

The second component, related to the first, but with sectoral limitations, is more or less reluctant mercantilism in foreign trade policy in all four countries ${ }^{19}$ :

There has been, and still is, infant industry protection as advocated even in neoclassical models of international trade. The instruments vary

- from tariffs, non-tariff barriers and preferential access to credit and foreign exchange in

Taiwan and Korea,

- to the establishment of state-owned enterprises in Singapore and Taiwan,

- and to technological support programs in Korea, Taiwan, and most recently, Hong Kong.

There has been currency undervaluation and thus export promotion in all four countries over prolonged periods, and it matters little whether it was guided, or not, by purposeful neomercantilist "beggar-thy-neighbour" motivation. There is, in any case, a striking difference to the protectionism that prevailed over most of the 1970s and 1980s in Latin America. As exemplified by Paul Prebisch's thinking, the Latin American dogma was to insulate developing countries from trade with industrialized countries altogether. The Asian NIEs have indeed protected their infant industries against imports from industrialised countries, but at the same time they have engaged wholeheartedly in exports of manufactured goods, even export-led macroeconomic growth on a massive scale. Their success is thus largely derived from participation in the world economy rather than from decoupling.

The third component is a dynamic free market economy, with applications of the Austrian school of economics long forgotten in North America and Europe under the dominance of Keynesian and neoclassical economics. Schumpeter's theories of forced savings, investment, innovation and business cycle have all been put to practice in the Asian NIEs as in Japan by generalist businessmen, bankers and industrial policy- makers mostly unaware of the theoretical recovery they were making:

\section{Saving}

In the inflationary phases of the 1960s and 1970s "Schumpeterian entrepreneurs" were regularly "overborrowing" and "overinvesting", securing from credit-creating banks or 
from the state the funds necessary to raid the circular flow of goods and services, forcing the economy to save by inflation ("forced saving"). Only Korea resorted to the massive capital imports that in the Harrod-Domar model of economic development are supposed to precede growth in developing countries. Taiwan has, like Japan before it, endeavoured to control its external debt and relied more on domestic savings. Singapore and Hong Kong, after the war, focused on the development of an efficient and free capital market in addition to indirect finance. What was common to all four Asian NIEs as to Japan was a widely above-average saving rate of private households that allowed their economies to proceed on a path of comparatively high growth even after inflation abated in the 1980s and the saving/investment balances turned around, at least in Taiwan, to an excess of saving over investment.

\section{Investment}

Schumpeterian entrepreneurs were able to continue making more than incremental investment decisions, climbing up at a high pace the scale of value-added production, vigorously entering global competition in marketing of new products, participating in the Schumpeterian supply-push innovation led by Japan ${ }^{20}$.

\section{Business cycles}

31 Rather than on short-term cycles of Keynesian demand, entrepreneurs and governments of the Four focused on seizing the opportunities of medium- and long-term cycles resulting from technological change of the Schumpeterian type. The most prominent example is their active participation in the so-called "second industrial revolution" provoked by the application of microelectronics to commercial products marketed on a global scale.

The fourth comparable component is the presence of factors essential for stable growth according to neoclassical theory. Stability of government, maintenance of competition in a basically market-oriented economy, population increase, import of technology, exploitation of comparative advantage, labour mobility and improvement of labour are factors that have all been common to the Asian NIEs.

The fifth component is that although the political regimes in power in the four countries just as in Japan are unmistakably conservative ${ }^{21}$, they have developed a remarkable ability to prevent or diffuse the potential of social conflict inherent, according to almost any historical record, to processes of rapid industrialization. The conservatism of these political regimes has obviously been a creative one, to use T.J. Pempel's formula for Japan's political culture. Social disequilibria, although certainly present, were much less conspicuous, exacerbated and sanctioned by religion, fatalism or doctrine, than in Latin America for example. There has been a remarkable degree of openness of opportunity and a rapid process of income equalisation in all the four economies. In Korea, the spreading benefits of a highly performing capitalist economy have doubtless had an emancipatory effect and explain a large part of the successful drive towards democratization. A similar process appears to be on the verge of success in Taiwan. 


\section{Functional Holism and Critical Rationalism} and integration.

\section{Adaptation}

Just as general equilibrium theory in classical economics is not meant to describe any real economy, the moving equilibrium resulting from the interaction of Parsons' four functions is not intended to describe any real society. Admittedly, Parsons' theory is not easily falsified by empirical testing, and therefore, does not live up to the standard of a true theory in Popper's epistemology. It shares this defect, however, with general equilibrium theory. Moreover, the difficulty is not due to a lack of deductive quality but to the level of generality of sociological functionalism. On the other hand it is far from unthinkable to try to falsify Parsons' theory even on the level of social systems in national aggregates. Parsons' theory would be falsified if it could be proved that a particular society has survived over time despite consistent lack of any one of the four Parsonian functional requirements.

Some might point to the Soviet Union or other Communist countries that have survived under that form of organization notwithstanding the high degree of adaptive dysfunction in the Pareto sense that has become an axiom of the Soviet economy. On the other hand, one might consider Gorbachev's efforts at "glasnost" and "perestroika" as well as Deng's modernisation drive, as dramatic recognitions of that adaptive dysfunction and thus as one of the most persuasive confirmations of the relevance of Parson's functionalist approach. Similar dysfunctions can easily be found on the other end of the ideological spectrum in Latin American economies dominated by conservative oligarchies.

But short of outright collapse of any one of the individual societies of the developed or developing world, we do recognize salient differences in economic performance, policy implementation, maintenance of cultural patterns, and societal integration. Obviously, there is a plurality of states of balance at which Parsons' "moving equilibrium" can be achieved. Allowing for that plurality does not mean immunizing the theory to epistemological insignificance. Rather than relegating such differences to the "ceteris paribus" proposition reserved for "extraneous" factors as general equilibrium theories tend to do, we might usefully try to trace them to Parsonian functions or dysfunctions. We feel all the more encouraged to do so, since as explained above, there are remarkable degrees of congruence between established, though competing, academic paradigm and each of the four Parsonian functions of adaptation, goal attainment, pattern maintenance

The capability of a social system to survive and adapt to its given environment goes beyond passive acceptance of external conditions. It rests more particularly on the productive potential of the economy. There are, of course, various levels of analysis and generality determining the understanding of that most difficult Parsonian function. On the level of the society as a whole, the adaptation function is assumed by the economic subsystem. Parsons accepts classical economic theory for this subsystem and treats it as being governed by autonomous market forces and by general equilibrium in the Marshall-Pareto tradition ${ }^{22}$.

Since economic theory in the classical tradition deemphasises government policy there is no need for Parsons to distinguish between the levels of analysis of action and of 
structure. For arguments sake, I will follow Parsons' for a moment in this classical understanding of the economy.

In this sense, the four Asian NIEs stand out for their adaptive achievements since the war. As the structure of international trade changed, so did the structure of NIEs' exports: from transhipping activities to light manufacturing in textiles, toys, footwear and then electronics, in the case of Singapore and Hong Kong; from agrarian economy to heavy industry like steel, petrochemicals, shipbuilding, auto-making, mining, and up the ladder of added-value to ever more high tech components of the electronics industry in Korea and Taiwan. Exporters of all four countries have consistently endeavoured to invest in sectors with the highest growth potential globally. All this can be explained with apparent ease in terms of the classical theory of trade, division of labour, and evolving comparative advantage. Table 2 serves as a suggestive survey of the economic development of the Asian NIEs in the classical sense.

However, there is another level of analysis for the adaptive function which goes beyond general equilibrium theory and concerns the real-world environment of a society, namely the level at which the question arises how a particular national economy adapts to the availability or non-availability of material and human resources. An interesting issue arises at this level for the particular nations we are concerned with. Why is it that the four nations with the smallest endowment in natural resources and the most unfavourable relation between population and space, and this is true of Japan as well, are the most advanced in industrialization in the region? Some specialists of Japan offer an interesting variation of Ricardo's theory of comparative advantage: the more disadvantaged by scarcity of resources, exiguity of space and distance from its foreign markets, they argue, the greater a country's incentive to specialize in exports of manufactured goods with the highest possible added-value ${ }^{23}$.

\section{Goal Attainment}

41 Another answer might be sought in the next Parsonian function: goal attainment. The economy does not stand isolated but is in constant reciprocal relations with the other subsystems. The polity, that is, the organization of political institutions, has the task of mobilizing forces for the attainment of system goals. Therefore, if the economy is the producer of wealth, the polity has the power to use its wealth to attain collective goals. The most fascinating level of analysis at which this Parsonian function can be applied is of course that of economic policy, more particularly, its border-relation with the autonomous factors of the economy.

Starting after World War II with few natural resources, abundance of cheap unskilled labour and little foreign currency in an environment determined by the East-West conflict and the Chinese and Korean partition, these four countries have resolutely engaged in a policy of export-led growth, as explained, in step with the expanding international trade. Since the late 1960s, they shifted their investments whenever international demand shifted. There was massive government targeting, and government demand, even in Hong Kong which next to Japan was one of the economic beneficiaries of the Korean and Vietnam wars. But such government guidance both led and followed the changes in the international division of labour under way on a global scale. Government activities and autonomous factors were inextricably intertwined. Whatever the mixture, the comparative advantages built up by the Four in the process are "man-made", not a 
natural endowment such as the proverbial English wheat and the Portuguese wine of classical Ricardian trade theory. They are the long-run structural effects of determined economic policies and thus one of the best illustrations of why it is important to distinguish analytically between structure and action as in proposition one stated above. Long-term goals were consistently more important than short-term ones for policymakers of the four governments. As in Japan ${ }^{24}$, it is not easy to asses the importance of short-term Keynesian policies in the Asian NIEs. Since the saving/ investment balance was tipped towards investment in the first two postwar decades in all four of them, there was no typical situation for Keynesian domestic stimulus. Long-term development of the supply side was in the center of the preoccupations of the policy-makers from the end of the war until today. On the other hand, the four economies took advantage of the external demand-pull that resulted from Keynesian demand management in their customers countries in the industrialized world.

And finally, we must not overlook the effect of the maintenance of undervalued exchange rates which have been associated ever since the 1930s with Keynesian theory. Although it requires day-to-day intervention and reaction to short-term movements in foreign exchange markets, exchange rate policy in the four NIEs up to the end of the 1980s is best understood in the framework of long-term trade policy, as are the more microeconomic measures of infant industry protection mentioned earlier.

As a basic characterization, I submit that, in Tinbergen's categories of the theory of economic policy, qualitative structural policies prevailed over the orthodox quantitative fiscal and monetary policy mix, pragmatic trial-and-error methods over macroeconomic fine-tuning, individual methodology over aggregate methodology, critical rationalism in dynamic development over dogmatic thinking in static models. There is massive evidence of unorthodox policy-making, from Hong Kong's "Austrian" laissez-faire to Korea's stateguided build-up of the supply side.

Hong Kong's case is important as it is an even more striking example than Japan how the "Austrian" reluctance to engage in any sort of government's policy-making can be overcome in an environment otherwise determined by the untrammelled market model. Its policy-makers have discovered that there are times when free enterprise can fail to produce Schumpeterian dynamism. The concern over Hong Kong's electronics industry loosing out against Korean and Taiwanese industries has pushed the government in 1988 to what officials call "a radical departure". The government is entering the business of what it calls "developmental support". It is setting up among others, a digital communications laboratory and a customized micro-chip design center. It also reverts to a sort of "picking-up-the-winner" strategy by employing consultants to study promising new technologies with potential industrial applications, and to recommend whether support services should be provided to them.

Both Taiwan and Korea have much larger research organizations with the dual role of training engineers and transferring core technology. For example, the Taiwanese Industrial Technology Research Institute (ITRI) is developing a new motorcycle engine controlled by a microprocessor reducing fuel consumption and pollution. Korean government research institutions are cooperating with major corporate conglomerates such as Samsung, Goldstar and Hyundai to develop new turboblades for aircraft engines and the next generation of memory chips, the 4 Mega-byte DRAM (Dynamic Random Access Memory). 
Taiwan and Korea come closest to imitating Japanese government-funded precompetitive research cooperation, which in our book on Japan we have proposed to label with the verbal monster of state-guided private polypolistic supply-push innovation. The comparison is not quite complete though because of the more reduced number of big high technology firms Korea and Taiwan can boast. Post-research competition in the four NIEs can hardly be called polypolistic but oligopolistic at best. If there is one thing that is unique about Japan, it is the wealth and diversity of its corporate landscape in almost any industrial sector. I submit this is what endows Japan with the unmatched dynamism and competitivity of its industry and allows it to watch competition from the Asian NIEs with relative calm. Thanks to its relative bigness and the high degree of competition in its own industries, Japan can face the so-called Boomerang Effect of its investments and trade with the Asian NIEs and still remain an unrivalled leader in technological innovation ${ }^{25}$.

\section{Integration}

49 At the same level-of-analysis of economic policy, the third Parsonian function, the integrative function, would be defined as the guidance, enforcement or control system assuring the implementation of policies through means of law, customs, or mere moral persuasion. There is a great deal of variety among Asian economies in this area as well. For one, none of the Four can boast such a superbly Colbertist or Prussian bureaucray as Japan. And Chalmers Johnson's formula of a "soft authoritarianism" as a common explanation of assured implementation of policies in the four cases is both oversimplified and outdated.

Not much more helpful are the various models developed by political scientists in order to capture Japan's supposedly unique government-business relationship, such as the "bargaining model", the "quasi-command model", and the "network model"26. Their conceptual sophistication may serve to feature what is special about Japan, but it is not very good at explaining comparative results in terms of policy implementation. That does not mean that the Japanese case cannot serve as an example. But I argue that the case must be explained in categories easily applicable to other economies as well. These categories should be as close to generally used economic and legal theory as possible. In our work on Japan's strategic pragmatism, we have distinguished five models of integration, the absence or presence of which in other countries can suggest a great deal about why policy implementation has been effective or not ${ }^{27}$. They are:

- administrative guidance,

- implicit contracts,

- preparedness to establish a hierarchy between conflicting economic policies,

- and finally, what Adolf Lowe, in his theory of economic knowledge, has called "secondary controls".

51 Administrative guidance is a Japanese specialty only at first sight. Governments everywhere signal preferred courses of action to economic agents all over the world, only in a much less systematic fashion than in Japan, and only with bad conscience as it were. Keynesian policy incentives, subsidies, tax breaks, and the like occur everywhere and are signals to the beneficiaries about how they should behave. As in Japan, such guidance is non-compulsory. Freedom of choice is maintained. Japan has managed to develop the instrument in systematic fashion as one that relies less on material incentives than on moral persuasion in explaining the stakes that are involved in solving problems 
confronting the government, households or firms. A country that is both large and democratic like Japan requires an exceptionally qualified bureaucracy to operate such a system with success.

Governments of smaller countries like the NIEs may manage with less formidable bureaucratic standards. The evidence of such guidance is massive in Korea, Taiwan and Singapore. Authoritarianism may have compensated any lack of legal sophistication before democratisation and liberalisation set in. But it is by no means a necessary condition. Hong Kong proves that administrative guidance can function in an ideal laissez-faire regime. The Governor has used this instrument sparingly, but there is no doubt that the small, though powerful, business community of the Colony would think twice before refusing, without a sensible reason, his moral persuasion.

This brings me to the second model, which covers a significant part of the first: implicit contracts or "gentlemen's agreements". They raise the level of administrative guidance from a unilateral to a bilateral one. Many Japanese believe that Japan has the monopoly of that instrument. Arguments reach from their cultural tradition of not putting contracts into writing, to their reluctance even to spell out commitments of loyalty, and to their highly developed sense of give-and-take. This instrument, however, is used for economic policy purposes in the West as well. The term "gentlemen's agreement", although of British origin, has entered global terminology and covers the same type of implicit commitments. One particularly striking non-Asian example are the gentlemen's agreements concluded by the German Bundesbank, known to be one of the most orthodox neoclassical institution of the world, with leading German banks in order to prevent capital movements running counter to the exchange rate of the deutsche mark prefered by the Bundesbank for reasons of domestic price stability. In Asia, Hong Kong, for obvious reasons, has not difficulty with the term and the practice. As for Korea and Taiwan, the pattern is epitomized by the October 1987 stock market crash situation when banks, solicited by government, agreed in the true Japanese fashion to mobilize considerable funds in support of share prices in order to restore confidence. The banks complied, and so did the public. Everyone benefited from the recovery made possible by this implicitly gregarious move.

Notwithstanding their differences, all four NIEs are managed by a closely knit corporatist network, comparable in many ways with Japanese and Central European corporatism. With authoritarian rule on the decline, the decision-making process is increasingly losing its top-down unilateral direction. To cite the Financial Times ${ }^{28}$, "governments have come to recognise their own weakness in assessing how market trends will move worldwide for different products, and to realise their administrations are overstrained". It is increasingly difficult to know where the center of decision lies, even in the most dirigist of the four, namely Korea. Consensual modes of policy-making and implicit contracts have increasingly become the pattern of policy integration.

Secondary controls are one of the Western concepts that had to wait for Japan and the Asian NIEs, as it were, to be practiced in pioneering fashion. Economic incentives, macroand microeconomic ones are offered by governments everywhere on the basis of the theoretical assumption of the reaction of economic agents. Lowe calls these incentives "primary" controls of the economy. All too often, there are no "secondary" controls as to whether or not beneficiaries of the incentives performed in accordance with the assumption underlying the primary controls. Considerations of fairness as well as of 
policy effectiveness call for "sanctions" in case of noncompliance. Such sanctions cannot be of a penal nature but merely consist of swift discontinuation of the incentives or the exclusion of non-complying beneficiaries.

Thanks to a highly performing bureaucracy, Japan has had no problems with secondary controls. Thanks to their relatively small size and the corporatist virtue of their economies, the governments of Korea, Singapore, and Taiwan could easily manage a similar system. Hong Kong's history of government incentives is extremely recent, as we have seen, but it evolves along the same lines.

One example I could cite is the story of the determined action of the Monetary Authority of Singapore (MAS) in 1985. The MAS had offered extremely favourable conditions to foreign banks for establishing themselves both in the domestic and off-shore markets. The off-shore facilities were the incentive provided for operating a domestic branch. The purpose was attraction of foreign capital. When Singapore was hit by a cyclical recession, the MAS attempted to reach with the major banks a gentlemen's agreement of the type just described in the case of the Bundesbank. The aim of the agreement was to offset a speculating run out of the Singapore dollar. The MAS argued that a cheaper dollar would increase the cost of imported components of manufactured goods and thus ruin Singapore's price competitivity as only 20 percent of export prices depended on wage and locally made components. Facing the non-compliance with the gentlemen's agreement, the MAS was provoked into applying the secondary controls of revoking the primary incentive of freedom of transactions between domestic and off-shore markets ${ }^{29}$.

There were marked differences in the choice of hierarchy between conflicting economic policies among the Four, but the choices were made as pragmatically and decidedly as in Japan and with much less doctrinal inhibitions than in Europe. For example, Taiwan subordinated industrial policy to neoclassical competition policy unequivocally, but did not reject industrial policy altogether, as West Germany still feels obliged to do. Korea and Singapore, just as unequivocally, subjected concerns of fair trade to those of industrial policy, while Hong Kong left it to its Schumpeterian entrepreneurs to fight among themselves over the concrete shape of market forms in the advanced sectors of the economy. Small and medium-size enterprises were also left to their fate, not only in Hong Kong, but in Taiwan and Singapore, while they were mostly integrated in a conglomerate network in Korea as in Japan.

Japan has been the pioneer of managing trade to prevent market disruptions in importing countries. Here, too, a clear hierarchy of policies was established. Fair trade policy would serve trade policy through legalisation of exporting cartels setting percentage shares of firms in total exports of designated goods to importing countries threatening protectionist action. Managing markets this way is wholely contested by economic theory because, preventing short-term market disruptions is not its only effect. In the long run, it is intended to guarantee all the more secure market penetration. In addition, it offers exporters that extra rent of scarcity resulting from reduced supply at higher prices (example: Honda cars in Europe and America). Importing countries are not well advised to call for such export restraints, but they regularly do so nonetheless, when faced with overcompetitive supply from East Asia, most prominently the U.S. and the EC. Korea and Taiwan have imitated the Japanese example and have penetrated the U.S. market all the more effectively. 


\section{Pattern Maintenance}

61 The pattern maintenance function is that part of Parsons' framework covering the field in which most Asian experts specialize: tradition, culture, value systems, in short, everything that is different in Asia as compared to the rest of the world, or, in each of the four countries, as compared to the other three and the rest of the world. While relegating such particular structural conditions to the periphery of theoretical interest in their characteristic ceteris paribus propositions, even general equilibrium theorists do recognize the impact of structure as axiomatic, i.e. as not having to be proved.

This is the field of cultural explanations of economic performance, such as the thesis that only Confucianism made Japan's, Korea's and Taiwan's performance possible, and only Asian countries with Chinese majorities like Hong Kong and Singapore could emulate that performance. Followers of this approach have the problem of explaining the People's Republic of China's lesser performance. There is a wide consensus that below the large official Marxist doctrine, Confucian values are still deeply rooted in Mainland China as well.

The monocausal Confucian explanation of the outstanding performance of the Asian NIEs is not well equipped to explain China's economic troubles before as well as after Mao. What is needed, is a functional approach balancing adaptation, goal attainment, and integration with cultural values (pattern maintenance). The functional approach helps focusing on adaptive dysfunctions of China's Marxist economy, especially in the area of price determination and production planning, which Deng's modernization program hopes to overcome. It can lead to the comprehension of the practical problems of a less than perfect bureaucracy in a big country, in terms of the integrative function. It also invites increased attention to the potential of pragmatic action across the cleavages between centralized government policy and decentralized market decisions in China's future as a two-economic-orders-in-one-state case ${ }^{30}$.

Such functional explanation seems over-ambitious to many, as it covers the field of various disciplines in a holistic framework. But in fact, it is less ambitious and conforms better to the scientific standard of critical rationalism than monocausal explanations in terms of only one of the disciplines it covers.

The same is true if we shift away from the level of analysis of societal macrostructures to the level of particular patterns of each of the four Asian NIEs. There is much diversity, but are also crucial similarities. In all the four cases, we have dualist economies as in Japan. There is the duality of traditional and advanced sectors, of the multitude of small enterprises and big conglomerates, of wages of temporary and permanent workers, of lifetime and temporary employment. The social cost involved in some of these dualities is considerable, but on the whole, they account for a sizeable part of the capacity for economic and social adjustment in the NIEs. On average, all sectors of their societies have greatly benefited from that adaptive performance. The functional relation of adaptation and pattern maintenance is obvious here.

There are many more structural patterns worth analyzing and I will mention only one more to which I have already referred earlier: the saving performance. A far above average saving propensity is common to all four. The average gross saving rate for the Four turns around 33 percent over the period 1980-1986, similar to that of Japan's 32 
percent, and more than double that of the U.S.' 15 percent, or that of the U.K., Australia and New Zealand, which also happen to be the biggest customers of the NIEs.

Nothing catches the dynamism of the four economies better than the fact that, even at this staggering saving rate, the saving/investment balance was tilted towards investment in all four cases during most of the postwar decades, until the mid-1980s. The balance was settled at an extremely high level indeed.

I admit that there is a feed-back loop to Confucian explanation since frugality and saving do rank high in Confucian values. But there is a catch to this. It does not explain everything. The same frugality and attachment to saving rank high in the theory of Western capitalism, Weberian or not. Capitalism is a pluralistic affair in terms of religions ${ }^{31}$. The question remains why other capitalist countries have performed less well than the Asian NIEs. Healthy capitalism may thus be a necessary condition of high economic performance, but not a sufficient one. To the question of what the sufficient condition ought to be, I have a tentative answer: a functional approach to theory, a strategic pragmatism in economic policy, and a flexible balance between private and public policy activities.

Table 1: Selected foreign trade indicators (1989)

\begin{tabular}{|l|l|l|l|l|l|}
\hline & Hong Kong & Korea & Singapore & Taiwan & Japan \\
\hline as \% of GPD & 232,00 & 66,00 & 369,00 & 98,50 & 35,40 \\
\hline \% of trade with Japan & 12,00 & 25,00 & 15,60 & 14,50 & \\
\hline \% of trade with US & 17,00 & 31,00 & 24,00 & 38,70 & 29,10 \\
\hline Total & 29,00 & 56,00 & 39,60 & 53,30 & \\
\hline Export: \% of manufactured goods & 87,00 & 94,70 & 25,60 & 86,40 & 93,10 \\
\hline Import: of raw material & 50,00 & 38,60 & 8,70 & 64,50 & 33,10 \\
\hline Energy & 2,00 & 5,80 & 26,60 & 7,60 & 34,00 \\
\hline
\end{tabular}

Source: Far Eastern Economic Review: Asia Yearbook 1990, pp. 8-9. 
Table 2: Selected Performance figures (1988)

\begin{tabular}{|l|l|l|l|l|l|}
\hline & Hong Kong & Korea & Singapore & Taiwan & Japan \\
\hline $\begin{array}{l}\text { per capita } \\
\text { income US\$ }\end{array}$ & 9643 & 4040 & 8162 & 5520 & 15500 \\
\hline $\begin{array}{l}\text { GDP real } \\
\text { growth 88\% }\end{array}$ & 7,30 & 16,00 & 11,00 & 7,34 & 5,10 \\
\hline \% avg. growth GDP 84-88 & 8,40 & 17,50 & & 9,71 & 4,52 \\
\hline
\end{tabular}

Source: Far Eastern Economic Review: Asia Yearbook 1990, pp. 8-9.

Table 3: Selected Foreign Trade Indicators (1983)

\begin{tabular}{|c|c|c|c|c|c|}
\hline & Hong Kong & Korea & Singapore & Taiwan & Japan \\
\hline As \% of GNP & $163.6^{*}$ & 84.4 & 306.4 & 101 & 29.7 \\
\hline$\%$ of trade with Japan & 17.9 & 19.0 & 14.2 & 17.8 & - \\
\hline$\%$ of trade with the US & 26.2 & 28.7 & 16.5 & 35.0 & 24.7 \\
\hline Total & 44.1 & 47.7 & 30.7 & 52.8 & - \\
\hline Exports: \% of manufactured goods & 87.8 & 94.4 & 46.4 & 93.1 & 96.5 \\
\hline $\begin{array}{l}\text { Imports: \% of } \\
\text { raw materials } \\
\text { petroleum }\end{array}$ & $\begin{array}{l}14.7 \\
6.5\end{array}$ & $\begin{array}{l}45.8 \\
21.3\end{array}$ & $\begin{array}{l}12.1 \\
31.3\end{array}$ & $\begin{array}{l}48.7 \\
20.1\end{array}$ & $\begin{array}{l}28.9 \\
36.2\end{array}$ \\
\hline
\end{tabular}

${ }^{*}$ GDP and not GNP

Source: Far Eastern Economic Review, Asia Yearbook 1985, pp. 8-10.

\section{NOTES}

1. Henrik SCHMIEGELOW and Michèle SCHMIEGELOW, "Teng's Modernisation and the ROC's Development Experience", in King-yuh Chang ed., Ideology and Politics in Twentieth Century China (Taipeh : Institute of International Relations, 1988), pp. 150-173; H. and M. SCHMIEGELOW, "Eléments corporatistes des récents concepts de réforme des entreprises publiques en Chine", paper presented at the Septièmes Journées d'Etudes sur la Chine Contemporaine, Paris, June 6-8, 1989. 
2. Michèle SCHMIEGELOW, "Puissance et Interdépendance : Le nouveau rôle mondial du Japon", Res Publica, Vol. XXIX № 4 (1987), pp. 555-574; and Henrik SCHMIEGELOW, "How Japan Affect the International System ?", International Organisation, vol. 44 n 44 (Fall 1989), pp. 553-88.

3. Max WEBER, The Protestant Ethic and the Spirit of Capitalism (London : Allen \& Unwin, 1930); id., Society and Economic Organization (New York : The Free Press, 1947).

4. Henrik SCHMIEGELOW and Michèle SCHMIEGELOW, "Japan's Perceived Uniqueness and the Relation of Structure and Action in Japan's Economic Performance", Paper presented to the Japan Economic Seminar at Columbia University, New York, April 9, 1988.

5. H. SCHMIEGELOW and M. SCHMIEGELOW, Teng's Modernization, p. 171.

6. Michèle SCHMIEGELOW and Henrik SCHMIEGELOW, Strategic Pragmatism : Japanese Lessons in the Use of Economic Theory, New York : Praeger Publishers, 1989.

7. M. and H. SCHMIEGELOW, Strategic Pragmatism, p. 9; Samuel HUNTINGTON, "The Change to Change: Modernization, Development and Politics", Comparative Politics vol. 3, 3 (1971), pp. 238-322; Jon ELSTER, Explaining Technical Change : A Case Study in the Philosophy of Sciences (Cambridge : Cambridge University Press, 1983), pp. 49-68.

8. For a discussion of functional explanation as opposed to causal and intentional ones, see Robert K. MERTON, Social Theory and Social Structure (Glencoe 111. : The Free Press, 1957), pp. 30ff; ELSTER, Technical Change, pp. 57, 242, n. 19.

9. Talcott PARSONS, the Structure of Social Action (New York : The Free Press, 1968) (1937); id., The Social System (New York: The Free Press, 1951), pp. 26-36; id., Societies : Evolutionary and Comparative Perspectives (Englewood Cliffs N.J.: Prentice Hall, 1966), pp. 5-29.

10. Karl POPPER, The Open Society and its Enemies (Princeton N.J. : Princeton University Press, 1970), vol. 2, pp. 237-39, 26-64, 268-69, 363-64.

11. Joseph A. SCHUMPETER, Capitalism, Socialism and Democracy (London: Allen \& Unwin, 1949), pp. 421-24; Friedrich von HAYEK, The Road to Serfdom (Chicago : University of Chicago Press, 1956).

12. See John Morton WHITE, Pragmatism and the American Mind -Essays and Reviews in Philosophy and Intellectual History (Oxford : Oxford University Press, 1973).

13. See H. and M. SCHMIEGELOW, Strategic Pragmatism, pp. 10-11, 17.

14. For POPPER, piecemeal engineering is the only possible prescription for practical policy of any kind given the fallibility of human knowledge. See The Logic of Scientific Discovery (New York : Harper Torch Books, 1959), p. 57.

15. H. and M. SCHMIEGELOW, Strategic Pragmatism, pp. 1-17.

16. Gunnar MYRDAL, Asian Drama : An Inquiry into the Poverty of Nations (New York : Pantheon Books, 19683 vol.); see also his Rich Land and Poor : the Broad Toward World Prosperity (New York : Harper \& Row, 1957).

17. Alexander GERSCHENKRON, "Typology of Industrial Development as a Tool of Analysis", in Second International Conference on Economic History (Paris : Mouton, 1965).

18. Charles KINDLEBERGER, "Government and International Trade", Princeton Essays in International Finance, $n^{\circ} 129$ (July 1978).

19. For the concept of reluctant mercantilism see Henri and Michèle SCHMIEGELOW, "The New Mercantilism in International Relations: The Case of France's External Monetary Policy", International Organization, Vol. 29, 2 (Spring 1975), pp. 367-91.

20. See Gerald M. MEIER and Robert A. BALDWIN, Economic Development: Theory, History, Policy (New York : John Wiley \& Sons, Modern Asia Edition, 1957), pp. 88-9, 101-12.

21. Paul ENSOR \& Anthony ROWLEY, "The Performing Twins on a Greasy Pole", Far Eastern Economic Review (September 26, 1985), p. 100.

22. Talcott PARSONS and Neil SMELSER, Economy and Society (New York: The Free Press, 1956).

23. Gary SAXONHOUSE, "Tampering with Comparative Advantage in Japan", Testimony before the US International Trade Commission on Foreign Industrial Targetting, 1983. 
24. Henrik SCHMIEGELOW, Japans Aussenwirtschaftspolitik: merkantilistisch, liberal oder funktionell ? (Hamburg : Institut für Asienkunde, 1981), p. 50; Michèle SCHMIEGELOW ed., Japan's Response to Crisis and Change in the World Economy (New York : M.E.Sharpe, 1986), p. 16.

25. Myohei SHINOHARA, Industrial Growth, Trade and Dynamic Patterns in the Japanese Economy (Tokyo : Tokyo University Press, 1982); M. and H. SCHMIEGELOW, Strategic Pragmatism, pp. 41-74.

26. Yutaka KOSAI, "The Politics of Economic Management" in Kozo YAMAMURA and Yasukichi YASUBA eds., The Political Economy of Japan Vol. 1 (Stanford : Stanford University Press, 1987); Richard SAMUELS, The Business of the State (Ithaca N.Y.: Cornell University Press, 1987); Chalmers JOHNSON, "Political Institutions and Economic Performance" in Frederic DEYO ed., The Political Economy of the New Asian Industrialism (1986).

27. M. and H. SCHMIEGELOW, Strategic Pragmatism, pp. 141-80.

28. Financial Times, Survey (June 30,1988).

29. See details of the MAS intervention in V.G. KULKARNI, "Strong-Man's Dollar", Far Eastern Economic Review, October 3, 1985, p. 50-51.

30. M. \& H. SCHMIEGELOW, Deng's Modernization.

31. M. \& H. SCHMIEGELOW, Strategic Pragmatism, pp. 157-63.

\section{ABSTRACTS}

Most observers of the Pacific Basin economies have been looking at socio-cultural explanations of the success the so-called "NIEs", i.e. South Korea, Taiwan, Singapore and Hong Kong, have had in developing their economies in the last three decades. While these explanations are certainly worthwhile, they are not sufficient. We propose another one: strategic pragmatism. Pragmatism is a virtue usually associated with Americans, but Japan, and in its wake, the NIEs, practice pragmatism in their economic decisions. They do not shun one or the other economic theory on doctrinary grounds, but use any one of them as suits the need of the particular industrial sector they want to develop. They make the distinction between structure and action and tend to act even in conditions of uncertainty. They base their economic strategy on consensual relations between public and private sectors, and try to maintain a minimum of peace in labour relations. They are part of the world economy and are tuned to any change in demand and in the international division of labour. They tend to adapt structures to the need of action and they in turn try to follow Schumpeter's precept of creating a new demand for their new products. In a few words, their economy is characterized by active government involvement, a reluctant mercantilism, infant industry protection, currency undervaluation and a dynamic structure of capitalism.

\section{AUTHOR}

\section{MICHÈLE SCHMIEGELOW}

Chargée de cours à l'Université Catholique de Louvain 